
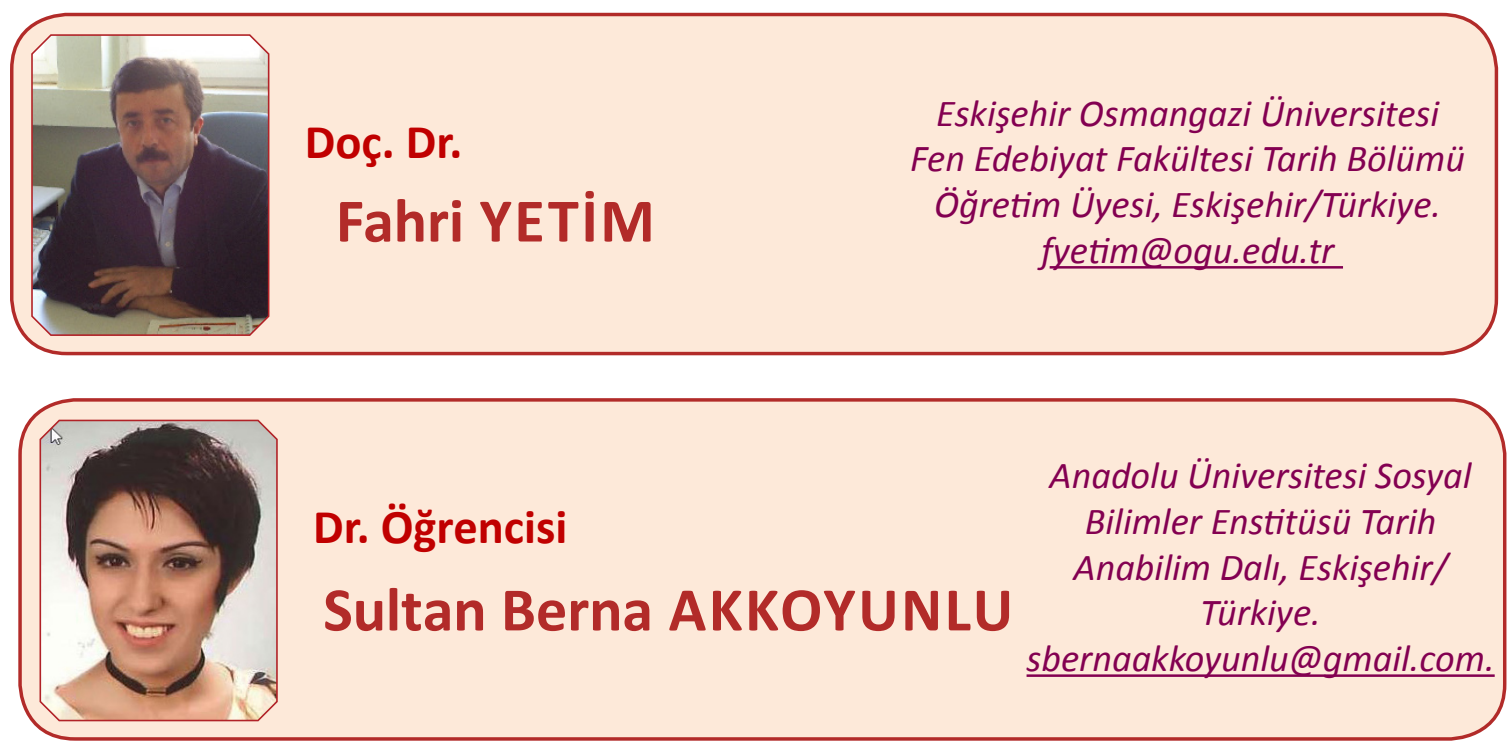

Eser Geçmişi: 18 Eki 2017 / 14 Kas 2017

DOI: $10.21551 /$ jhf.345039

\title{
Türk Modernleşmesine Erken Cumhuriyet Dönemi Basınında Karikatür Üzerinden Bir Bakış *
}

\author{
A Look at the Cartoons in the Press of the Early Republican Period in \\ Turkish Modernization
}

\section{ÖZET}

Türk basın tarihinde mizah kapsamı içinde karikatürün, farklı nedenlerden dolayı sınırlı sayılabilecek bir geçmişi olmakla beraber, basın kurumunun, özellikle siyasetle etkileşimi sonucunda ortaya çıkan zengince bir dağarcığından söz etmek mümkündür. Başka bir şekilde ifade edecek olursak, toplumsal değişim sürecinde mizah olgusu içinde karikatürün etkisi hacimle sınırlı kalmamıştır. Bu olguya erken Cumhuriyet dönemi açısından bakıldığında, Türk modernleşmesinde karikatür ekseninde siyasal hayat, kültür, toplumun duyuş-düşünce tarzı, mizah anlayışı, değişen değer yargıları gibi parametreler üzerinden yaşanılan değişimin izleri sürülebilir. Bu düşünceden hareketle, bu çalışmada erken Cumhuriyet dönemi basınında karikatürün yeri, işleniş biçimi, tematik yönleri ortaya konulmak suretiyle dönem toplumunun zihin gündemi değişik açlardan değerlendirilerek dönemin siyasi ve kültürel

* Bu çalışma, Eskişehir Osmangazi Üniversitesi Sosyal Bilimler Enstitüsü Doç. Dr. Fahri Yetim danışmanlığında yürütülen Sultan Berna Akkoyunlu'nun "Erken Cumhuriyet Dönemi Türk Basınında Karikatür (1923-1933)" adlı yüksek lisans tezinden yararlanılarak hazırlanmıştır. 
atmosferini nasıl etkilediğine ışık tutulmuştur. Çalışmada ayrıca Türkiye tarihi içinde, erken Cumhuriyet döneminde benimsenen modern toplum yapısı ve ulus devlet hedeflerinin gerçekleştirilmesinde basının ne denli işlevsel bir konumda bulunduğu ortaya konularak Osmanlı devri ile Cumhuriyet dönemi arasında geçirgen ve değişken yapıların durumu karikatür üzerinden mizah yoluyla sergilenmeye çalışılmıştır.

Anahtar Kelimeler: Karikatür, Modernleşme, Cumhuriyet, Basın, Mizah.

\section{ABSTRACT}

Although having occupied, within the context of sense of humour, a limited place in the history of Turkish press, and no matter for what reasons, one can speak of a rich repertoire of the institution of press, in regard to its interaction with politics, in particular. In other words, the impact of humorous caricature, with respect to its limited volume, did not remain limited during social change, Looking at the incident through the eyes of Early Republican Era, the traces of transformation undergone in such parameters of Turkish modernization as changing value judgmenets, sense of humor, manners of social conception and thinking, culture, and political life, can be followed by means of caricatures. From this point of view, the place of caricature in Early Republican Era, the way it was handled and the thematic aspects there of is set forth by the current research, and the intellectual agenda of the society of the time was subjected to various analyses, showing how they contributed to the political and cultural atmosphere of the age. The influential role of the press in the materialization of the formation of a nation state and a modern social structure, an objective adopted during the early years of the Turkish Republic, has also been pointed out. Finally, the state of the variable and permeable structures between the Ottoman and Republican era were attempted to be displayed still via caricatures.

Key Words: Caricature, Modernization, Republic, Press, Humour.

\section{GíRiş}

19. yüzyılda Türk modernleşmenin temel dinamiklerinden biri olan basının ortaya çıkışı, pek çok alanda yeni değişim süreçlerini gündeme getirmiştir. Yenileşme ihtiyacı (ıslahatı, değişimi savunma), dinamik bir kamuoyuna geçiş, laikleşme yolunda ilk adımlar, dile bağlı ulusçuluk düşüncesinin gelişmesi, Batılı kavram ve sözcüklerin tedavüle girmesi, haberden çok eğitim aracı olması dolayısıyla zihniyet değişimi bunlardan bazılarıdır ${ }^{1}$. Türk basının gelişim sürecini ise, Türk matbaasının kuruluşuyla başlatmak gerekir. Bu cümleden olarak, Fransa'ya gönderilen Yirmi Sekiz Mehmet Çelebi'nin tavsiyesi ile oğlu Said Mehmet ve İbrahim Müteferrika ortaklaşa imparatorluk sınırları içinde ilk Türk matbaasını 5 Temmuz 1727 yılında açmışlardır². Açılan Türk matbaasında müspet bilimler üzerine

1 Orhan Koloğlu, Osmanlı'dan 21. Yüzyıla Basın Tarihi, İstanbul 2006, 27-30.

2 Bernard Lewis, Modern Türkiye’nin Doğuşu, TTK Basımevi, Ankara 2004, s.52. 
Türkçe kitapların basılmasının yanı sıra zamanla din bilimlerine ait kitapların basılmasına da izin verilmiştir. Söz konusu hassasiyetin nedeniyle ilgili olarak, tarih alanında yanlış ve yaygın bir inanç haline gelen, dini yayınların yapılmasının ilk aşamada İslam hukukuna aykırı olduğu görüşü gösterilmiştir. Bununla beraber dini kitapların basılmasına izin verilmemesinin, dinsel bir sorun olmaktan ziyade siyasal bir önlem olarak düşünüldüğü gözden uzak tutulmamalıdır. Çünkü bu dönemden önce Ermeni, Yahudi ve Rum bölgelerinde basılan dini kitapların siyasal ve dinsel karışıklıklara sebebiyet verdiği görülmüştür ${ }^{3}$. Bundan dolayı devlet, ilk özel gazetenin yayınlanmasına kadar, matbaadaki görevlileri devlet memurlarından oluştururken, diğer

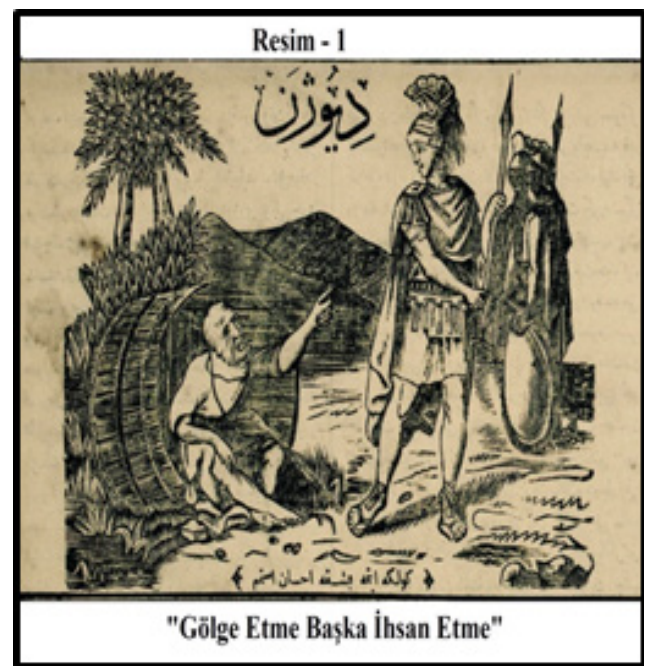
yandan basılan tüm eserleri de kontrolünde tutmuştur.

18. yüzyılda yaşanan savaşların getirdiği toprak kayıpları, buna bağlı olarak hazine harcamaları ve Hristiyan topraklarındaki vergi kesintileri Osmanlı Devleti'ni başta askeri ve siyasi olmak üzere birçok alanda batı kurumlarına yönlendirmiştir. ${ }^{4}$ Modernleşme için atılan adımların uygulanabilirliğinin sağlanabilmesi ve devamlılığının sürdürülebilmesinin, ıslahatların toplum tarafından desteklenmesine bağlı olduğu hususu idareci sınıf tarafından görülmüş ve bu gerçeklik sultan tarafından da kabul edilmiştir. Böylelikle ilk basın hareketleri ve organları, her ne kadar devlet eliyle desteklenmiş ve sadece haber verme özelliği taşımış olsalar dahi, gazete ile yeni tanışan Osmanlı Devleti'nde yapısal sorunların gündeme getirilmesi, bu sorunların çözümü doğrultusunda yapılacak atılımların halka duyurulası konusunda, devlet içinde ise yeni düşünce akımlarının oluşmasına ve modernleşme yönünde bir fikir devriminin oluşmasına imkân sağlamıştır. Özellikle Tanzimat döneminde Osmanlı basının gelişimi, orta sınıfının oluşmasına ve kültür liderliğini tekelinde bulunduran ulema sınıfının yerine yeni Osmanlı aydınının geçmesine yardımcı olmuştur. Bu durum aynı zamanda, kısa süre içinde Osmanlı yazın dünyasını etkilemiş ve Batı'dan ithal edilen tefrikalara veya sosyo-siyasal konulara yönelimin artmasına neden olmuştur ${ }^{5}$. 19. yüzyll. ortalarından imparatorluğun sonlarına kadar basın üzerinden sürdürülen sosyal iletişim, bir yandan önce Osmanlıcılık, daha sonra Türkçülük gibi akımların doğmasına neden olurken, diğer yandan da edebi alanda yapılan sadeleşme girişimlerinin yarattığı okur artışı da düşünsel

3 Müteferrika Matbaasında yayınlanan ilk yayınları görmek ve Osmanlı Basın hayatını hakkında fikir edinebilmek için bkz. Selim Nüzhet Gerçek, Türk Matbaacılığı I Müteferrika Matbaası, Maarif Vekaleti Yayınları, İstanbul 1939, s. 81-105; Mustafa Nuri İnuğur, Basın ve Yayın Tarihi, Çağlayan Kitabevi, İstanbul 1982, s. 153-165; Osman Ersoy, Türkiye'ye Matbaanın Girişi ve Ilk Basılan Eserler, Güven Basımevi, Ankara 1959, s.29-45. Ayrıca Osmanlı devleti sınırları içinde çıkan Türk basını dışındaki diğer yayınların ortaya çıkardığı sonuçlar için bkz. Niyazi Berkes, Türkiye’de Çă̆daşlaşma, Yay. Haz. Ahmet Kuyaş, Yapı Kredi Yayınları, İstanbul 2011, s.58-60.

4 Osmanlı Devleti’nde ilk ıslahat fikirleri, kalıcı olmasalar bile, Damat İbrahim Paşa aracılığı ile "Lale Devri” nde görülmüştür. Gönderilen elçilerle yeni bayındırlık ve eğitim araçları İmparatorluk sınırlarına girmiş olmasının yanı sıra bu dönemde Fransız subayların raporlarıyla orduda yenileşme hareketleri başlamıștır. İran ile savaşların devam etmesi ve İstanbul'da ayaklanmanın patlak vermesi denizcilik ve askeri alanda yeni 1slahatların ortaya çıkmasına zemin hazırlamıştır. Ayrıntılı bilgi için bkz. Lewis, a.g.e., s. 46-54, Berkes, a.g.e., s.41-49.

5 Stanford J. Shaw, Ezel Kural Shaw, Osmanlı Imparatorluğu ve Modern Türkiye, E Yayınları, İstanbul 1994, s. 166. 


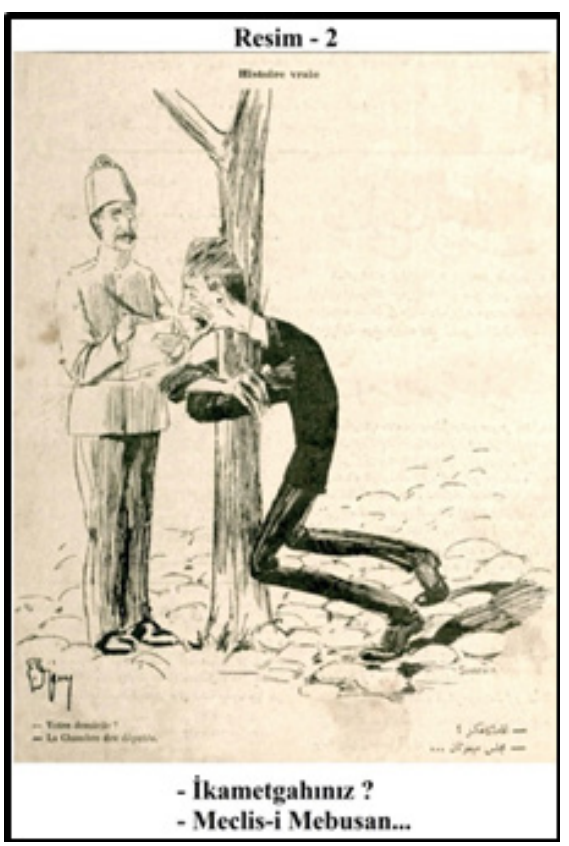

modernizasyon sürecine ivme kazandırmıștır ${ }^{6}$. Öte yandan modernleşme sürecinde yaşanılan bu gelişmeler, zihniyet düzleminde farklı algılamalara yol açmış, bu durum ise sürecin içselleştirilmesi noktasında mizah olgusunu gündeme getirmiştir. Mizahın güçlü enstrümanlarından biri olan karikatür de erken dönemlerden itibaren devreye girerek bu sürece önemli katkılar sağlamıştır.

Türkiye'de mizah ve münhasıran karikatür üzerine yapılmış hatırı sayılır bir çalışmadan söz edilebilecek olunmasına rağmen bu konu; bu çalışmada ele alınan yönüyle incelenmiş bir konu olmaktan oldukça uzaktır. Yapılan çalışmalar genellikle, modernleşmeyi radikal bir şekilde savunan (dolayısıyla ideolojik), dayatmacı bir çizgide olup, eleştiride tek yanlı ve toplumun kültürel duyarlılıklarını göz önüne almayan, yabancılaşma endișelerini hesaba katmayan bir bakış açısıyla yapılmıştır. Dolayısıyla bu çalışmanın özgünlüğü, mevcut çalışmalarda sözü edilen zaafları yansıtan ve söz konusu duyarlılıkları ıskalayan yaklaşımlara ilişkin getirdiği eleștirel perspektifte aranmalıdır.

$\mathrm{Bu}$ çalıșmada, Türk modernleșmesinin en önemli aşamalarından biri olan erken Cumhuriyet döneminde mizah olgusu içinde karikatürün modernleşmedeki işlevi değerlendirilmiştir. Çalışmanın temel problematiği ise, köklü bir geleneksel potansiyeli olan Türk toplumunun, radikal modernleşme projesi karşısındaki direncinin kırılmasında karikatürün ideolojik işlevinin ortaya konulmasıdır. Çalışmada yöntem olarak, oluşturulmaya çalışılan yeni kültür ortamı içinde yer alan yeni değerlerin topluma mal edilmesinde görsel malzemenin (karikatürün) betimlenmesi ve tahlili yöntemi kullanılmıştır. Yöntem içinde ayrıca söz konusu döneme gelinmeden önce modernist zihniyetin temel izleklerinden biri olan karikatürün Türkiye'deki tarihsel gelişimini yansıtan kronolojik bir anlayıștan hareket edilmiştir.

\section{SÜRECI \\ TÜRK KARİKATÜRÜNÜN ORTAYA ÇIKIŞI VE GELIŞiMIM}

Anadolu topraklarında yaklaşık 150 yıldan beri varlığını sürdüren karikatür, düşüncelerin çizgilerle anlatılmasını sağlayan en etkili yollarından biri olup yalnızca güldürü sanatının bir parçası olarak kullanılmamıştır. Çünkü mizah, nitelikli olsun veya olmasın, günlük yaşamın ve klișe fikirlerin basına yansıması değil, kamuoyu yaratma gücüne sahip ideolojik üretim ve dağıtım araçlarıdır.

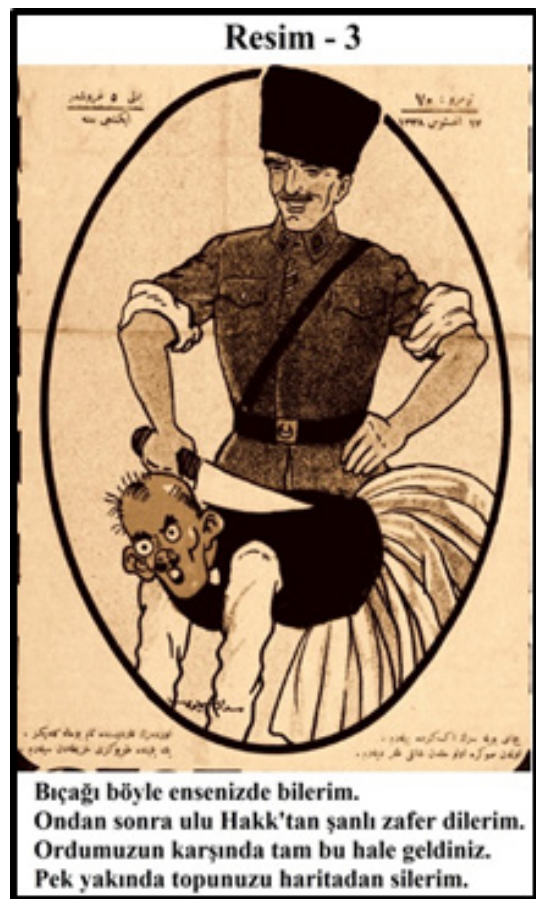

6 Şerif Mardin, Türk Modernleşmesi Makaleler 4, İletişim Yayınları, İstanbul 1992, s.144-156. 
Osmanlı kültüründe karikatüre bir ön tarih oluşturacak öğeler arandığında, minyatür ve Karagöz tasvirleri öne sürülür. Bunlar yapısal açıdan karikatürel nitelikler taşımalarına karşın, bu amaçla yapılamamışlardır. Başka dönemlerin, farklı süreçlerin ürünleridir; Minyatür basın ortaya çıktığında çoktan devrini kapatmış, Karagöz ailesi ise, sözlü mizahın gözdelerinden biri olarak devam etmiştir. Karagöz tipinin, yazılı basında bir türlü vazgeçilememesinin nedeni, karikatürcülerin kültürel birikimi, sözlü mizahla dolu olması ve biçimsel olarak karikatüre çok benzemesinden ileri gelmektedir. ${ }^{7}$

Osmanlı Devleti'nin Tanzimat döneminde başlayan karikatür, yer yer Fransız ve azınlık basının etkisinde kalmış olmakla beraber, bu yöndeki bilincin yapı taşlarını oluşturmuştur. Devlet sınırları içinde çıkarılan ilk mizah dergisi, 1852 yılında Hovsep Vartanyan Paşa tarafından Ermenice olarak çıkarılan Boşboğaz Bir Adem adlı dergidir.Bunun dışında Ermeniler başta Meğu olmak üzere daha pek çok mizah dergisi yayınlamıştır. Daha sonra Türk mizah dergisi çıkıncaya kadar Ermeniler, mizah basınında etkin bir rol oynamışlardır.

Basın tarihçisi Atilla Özer'e göre, ilk karikatür (Resim1) ${ }^{8}$ 23.11.1871'de bağımsız olarak Teodor Kasab tarafından yayınlanan mizah dergisi Diyojen de ortaya çıkmasına rağmen, Terakki gazetesinin 1870 yılında basımına başlanan ve abonelerine ücretsiz olarak dağıtılan aynı isimli mizah ekinde, ilk Türk karikatürlerinin bulunduğu görülmektedir. ${ }^{9}$

Bununla birlikte eğitim, kültür, siyaset ve yolsuzluklar üzerine çizimler yapan ve 183 sayı yayınlanan ilk mizah dergisi sayılan Diyojen'in kapanmasıyla Teodor Kasab; Çıngıraklı Tatar ve Hayal mizah dergilerini yayınlamaya başlamıştır.

$\mathrm{Bu}$ dönem karikatürlerinin çizgilerinde, resimsellik ve karagöz biçimlerinin baskınlığı görülmektedir. Konu olarak ise yanlış batılılaşmayı, tepeden inme getirilen yenilikleri

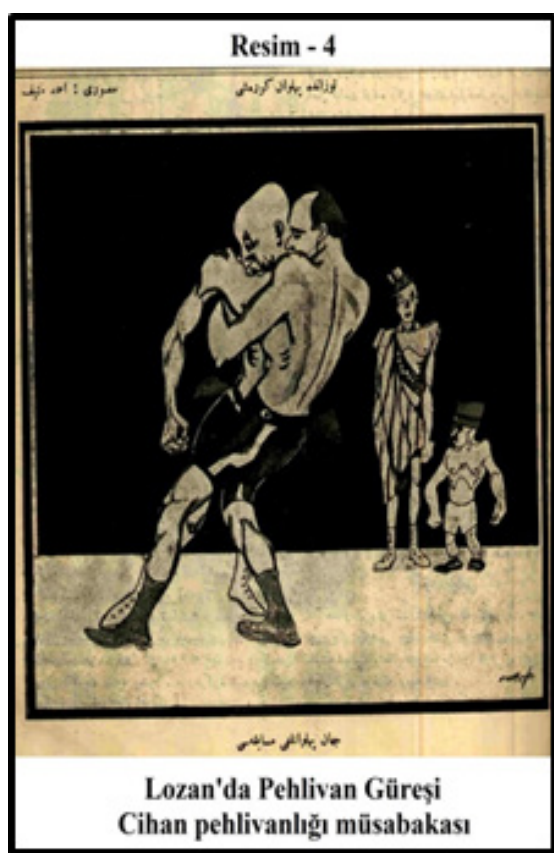
eleştirmiş, kadın erkek ilişkileri incelemiştir. Ayrıca karikatürlerle cephe gerisindeki halkı umutlandırmayı ve yılgınlığı ortadan kaldırmayı amaçlamıștır. Bu suretle Türk karikatürü, Tanzimat döneminde sıfır noktasından başlayarak, kendini çağdaşlaşma savaşının içinde bulmuştur.

II. Meşrutiyet mizah yayınları ve karikatürleri, biçimsel formları, çizer kadroları veya felsefeleri açısından farklı özelliklere sahiptir. Karagöz - Hacivat geleneğini devam ettiren ve halk mizahı figürlerini kullanan Karagöz, Hacivat, Nasrettin Hoca, Feylesof, Köylü gibi yayınların yanı sıra materyalist düşüncenin savunucu olan Eşşek, eşekler dünyasının aracılığı ile insanları

7 Turgut Çeviker, Gelişim Sürecinde Türk Karikatürü-I Tanzimat ve Istibdat Dönemi (1867-1878/1878-1908), Adam Yayınları, İstanbul 1986, s.17.

8 Teodor Kasab, Diyojen, 12 Teşrin-i Sani 1289, no:1, s.1.

9 Atilla Özer, Karikatür Yazıları, Anadolu Üniversitesi Yayınları, Eskişehir 2007, s.2. Ayrıca yapılan literatür araştırmasında görülen ilk resimli gazete 1867 yılında yayımına başlayan Ayine-i Vatan gazetesidir. Resimlerin ilkelliği ve klişe giderlerinin karşılayamamasından dolayı kısa sürede kapanmıştır. Daha sonra farklı isimlerle yayımına devam etmiş olsa da uzun soluklu olamamıştır. 
ele alarak sert ve kara yergiyi çizgiye taşımıştır. Batılı modern mizah anlayışının öncüleri ise Kalem (Resim-2) ${ }^{10}$, Cem, Diken, Karikatür, Hande adlı yayınlardır. Özellikle Kalem, Avrupa'dan getirttiği ve Avrupa'da yetișen Cemil Cem, Sedat Nuri gibi çizerlere kadrosunda yer vererek, toplumdaki devrim sürecini karikatürlere de taşımış, modern karikatür dönemini açmıştır. Ayrıca Tanzimat ve İstibdat döneminin karikatürleri resim olarak nitelendirilirken Meșrutiyet döneminde de karikatür sözcüğünü ilk kez Kalem'de kullanılmış ve Cemil Cem kendince karikatür tanımı yapmıştır:

"Karikatür!... Kapsamı geniș büyük bir sözcük! Güldürmek için biraz yarı şaşı baktıran bir göz, biraz

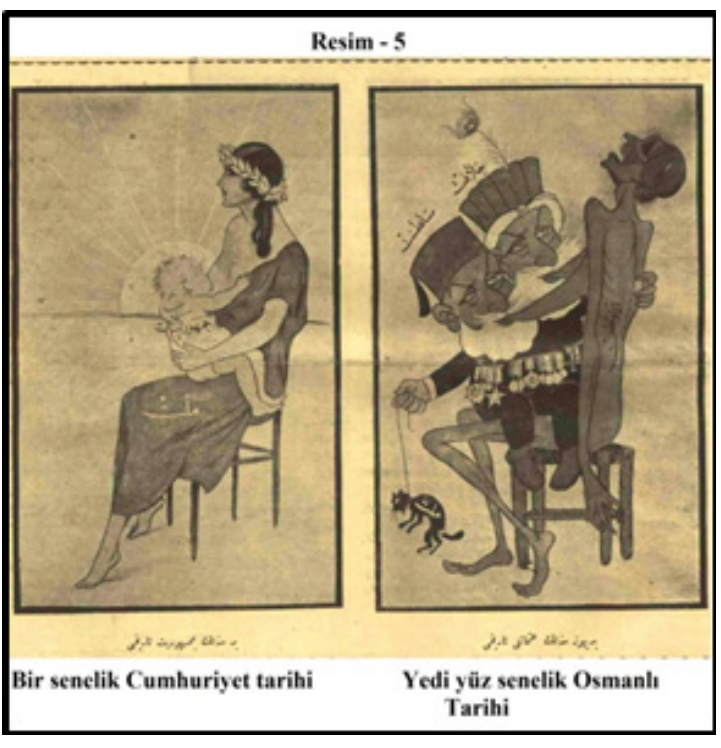
büyütülen bir buruncuk, biraz sırıttırılan bir ağız, yampiri çiziverilen bir çizgi, kimileyin bir kızgınlık yaratır. Güldürecekken kızdırır. Melek bir düşünceyi, ifrit bir düşmanlık içine sokar. (...) Karikatür; nükte, anıştırma, mazmun gibi edebiyat sanatından sayılır. Bu kanıtlarla edep alanında, hem yalnız edep alanında uçması gerekir. (...) Karikatür hiçbir zaman kötü düşünmez, hep tuhaf düşünür(...)"11.

Genel olarak II. Meşrutiyet dergilerine baktığımızda Karagöz ve Kalem'in dışındakiler ya karikatür kullanılmamıștır ya da Tanzimat karikatürünü geliştirerek sürdürmüşlerdir.

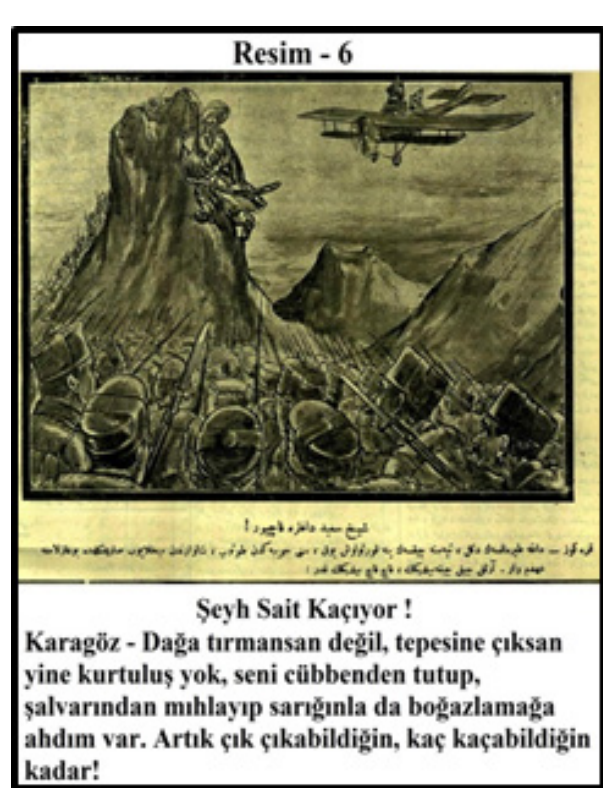

Fakat Kalem'in ortaya çıkışı ile birlikte mizah ve karikatür döneminde yeni bir çı̆̆ır açılmış ve Cem'in Kalem'e katılmasıyla karikatürün yeniden doğuş savaşı da toplumsal değişim gibi hızla başlamıştır. Böylece Kalem, yeni olanın doğum evi olmuştur.

Anadolu’da başlayan Milli Mücadele, Osmanlı Devleti topraklarında yaşanan hiçbir savaşa benzememektedir. Mustafa Kemal'in önderliğinde verilen Milli Mücadele sadece cephelerdeki askeri olaylarla sinırlı olmayıp, halkın topyekûn katıldığı bir süreci temsil etmekle birlikte Milli mücadele dış düşmanın yanında kurtuluş savaşına inanmayan ve ayaklanan iç güçlere karşı da verilmiş bir savaştır.

Milli Mücadele, Türk Karikatürü içinde önemli bir dönüm noktası olmuş ve savaş koşullarının etkisiyle tasvirci anlayışı devam edilmiştir. ${ }^{12} 19$ Mayıs 1919 öncesi mizah basını, dolayısıyla karikatür,

10 Salah Cimcoz, Kalem, 8 Kanun-i Sani 1324, no:21, s.1.

11 Münir Süleyman Çapanoğlu, Basın Tarihimizde Mizah Dergileri, Garanti Matbaası, İstanbul 1970, s.114-117. Ayrıca metnin aslına ulaşmak için bkz. Salah Cimcoz, Kalem, 21 Ağustos 1324, no: 1, s.3.

$12 \mathrm{Bu}$ dönem çizerlerin birçoğu önemli eğitimler almış Sanayi-i Nefise Mektebi öğrencisi veya mezunu olduğundan çizgiler belirli kompozisyonlar üzerine inşa edilmiştir. 
tüm imzalarıyla aynı hedefe doğru bütünleşirken, Ulusal Kurtuluş Savașı döneminde milli mücadele yanlısı yayın organlarının yanı sıra, Anadolu'da başlayan harekete karşı olan, saltanat ve işgalci güçlerden yana tavır takınan bir grupta mevcuttur. ${ }^{13}$ Çizgiler kişileri ya "hain" olarak anlatmakta ya da "vatansever" olarak tanımlamaktaydı. Dünyanın ilk antiemperyalist savaşında, milli mücadele yanlısı olan mizah basını, büyük sorumluluklar yüklenerek kendilerini savașçı, mizah dergilerini silah, karikatürlerini ise cephane olarak görmekteydi ${ }^{14} \quad$ ResimKemalist $^{16}$ Güleryüz dergisi arasında kanlı karikatür Güleryüz'ün çizeri Sedat işgalcilere ve işbirlikçilere parçalayıcı etkisiyle bir karikatür ortaya çizerlerinden Münif Fehim, seçtiği dizeleri süsleyerek Türk mizahına ince bir Ramiz Gökçe, çizgilerinde yaşatarak kimi kez groteske sağlam yapılı bir desenle portre çalışmaları yaparak, bir bakış açısı ortaya

Kurtuluş başarılarından

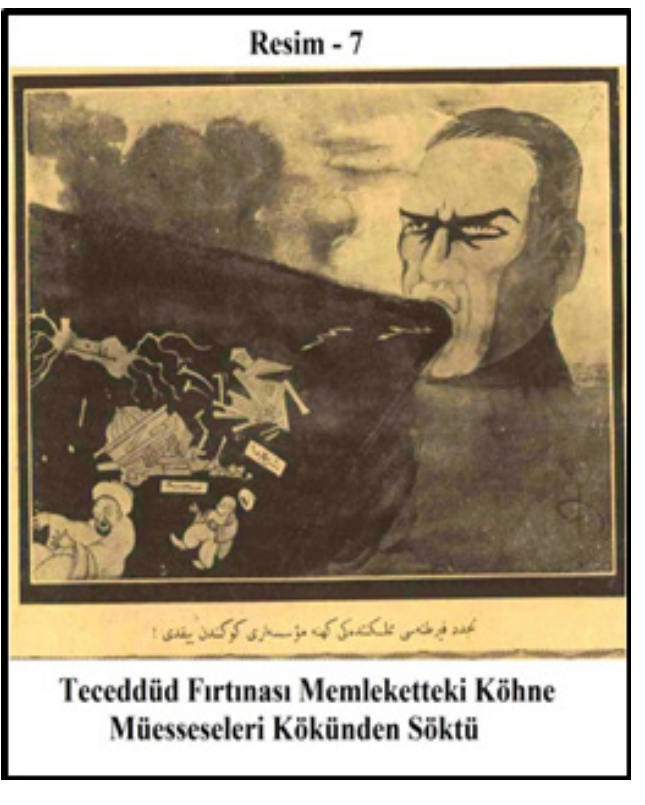
3) ${ }^{15}$.Özellikle İstanbul'da ile karşıtı Aydede dergisi savaşları yaşanmıştır. Simavi ve Cevat Şakir karşı grotesk ${ }^{17}$ in yakıcl, saldırgan ve teşhirci koyarlarken, Aydede'nin divan edebiyatından karikatürlerine eklemesi, şiirsellik getirmiştir. sessizlikle öfkeyi iç içe uygun kaba, hantal ama çalışmıştır. Ratıp Tahir'de dönem mizahında yeni koymuştur. ${ }^{18}$

cephelerinde elde edilen ekonomik, siyasi ve sonra lanıldığında, Milli Mücadele karşıtı yazar ve çizerler ya yurt dışına kaçmış veya kalemlerini yumuşatmışlardır.

Lozan Döneminin karikatürlerinde silahlar veya cephaneler yerini anlaşma metinlere, kapalı salonlara, devlet başkanlarına bırakmış ve İsmet Paşa, elinde defne dalı veya "sulh meleği" olarak tasvir edilmiştir. Böylece karikatürist kendini yenileyerek anlatımını zenginleştirme fırsatını bulmuştur (Resim-4). ${ }^{19}$ Bunun dışında grotesk öğeler azalırken, yergi ve alay varlığını sürdürmeye devam etmiştir. Bu dönem karikatürlerinde hoşgörü ve horgörü aynı anda ilermiş ve Lozan'daki görüşmeler Türkler aleyhinde ilerlediğinde horgörü öne çıkmış ve çizgilerde toplumsal tehditler başlamıştır.

13 Bülent Akbaba, Togay Seçkin Birbudak, "Milli Mücadele ve Cumhuriyet Dönemi Mizah Basınında Mustafa Kemal Atatürk İmaj1”, Gazi Üniversitesi Gazi Eğitim Dergisi, C.2, Özel Say1, Ankara 2009, s.1254.

14 Turgut Çeviker, Gelişim Sürecinde Türk Karikatürü-III Kurtuluş Savaşı Dönemi (1918-1923), Adam Yayınları, İstanbul 1991, s.22.

15 Sedat Simavi, Güleryüz, 17 Ağustos 1338, no:70, s.1.

16 Kemalizm nitelemesi bilindiği kadarıyla ilk kez işgalci bir gazeteci tarafından kullanılmış ve Milli Mücadele’nin başarıyla devam etmesiyle ülke içinde ve dişında Mustafa Kemal'in önderliğindeki ulusal direnişin düşünsel ve eylemsel ismi olmuştur. Ayrıntılı bilgi için bkz. Şaduman Halıcı, Murat Burgaç, Altı Ok (1919-1938), Kaynak Yayınlar1, İstanbul 2016,s.31-35.

17 Dünyayı yabancılaştıran ve onu eğlenceli hayali bir alana götüren, içinde esrarengiz, tekin olmayan güçlerin egemenliğinin yansıdığı, aslında bir araya gelmez gibi görünen şeylerin, mesela trajikle komiğin, adilikle yüceliğin bir oyun havasında birleştirilmesi.

18 Turgut Çeviker, Gelişim Sürecinde Türk Karikatürü III, s.28.

19 Ahmed Münif, Kelebek, 24 Mayıs 1339, no:7, s.1. 


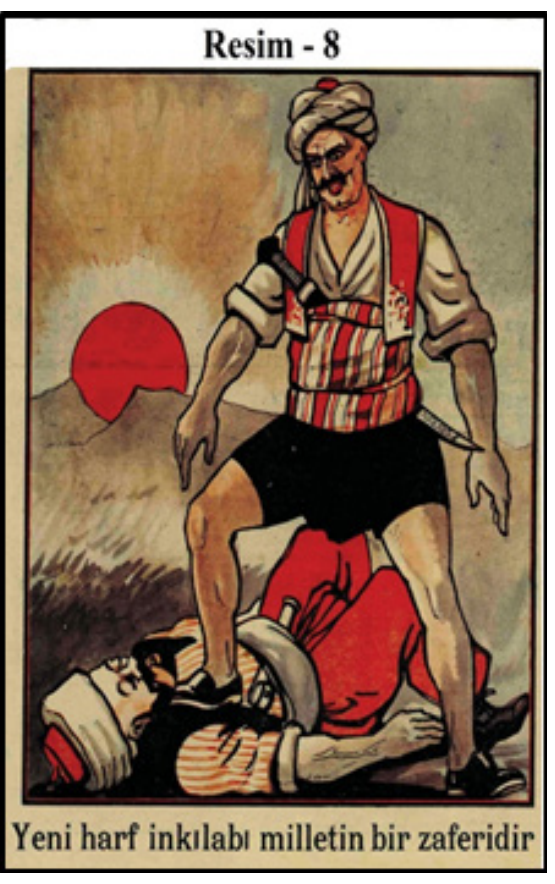

Meşrutiyet Döneminde "Avrupa"lı karikatüristler sayesinde olgunlaşan Türk karikatürü, savaş koşullarını yaşıyor olması sebebiyle de çizgileri modern bir değişime uğramıștır. Milli mücadele karikatüristlerinin çoğu, çizgi eğitimi gören Sanayi-i Nefise Mektebi öğrencisi veya mezunu iken, bir önceki dönemin çizerlerinin de etkisi bulunmaktaydı. Dönem karikatüristleri, savaş döneminde resimsellikten uzaklaşmış olsalar bile, barış görüşmeleri sırasında yeniden resime yaklaşmışlardır. Bu durum ise, çizgi estetiği açısından karikatür bilincinin henüz farkında olmadıklarını göstermektedir. Yaşanan savaş dönemi neredeyse tüm karikatürleri etkilemiştir. ${ }^{20}$ Ara renklere yer vermeden, kendi tarafında olan övülerek göklere çıkarılmış, karşı düşüncede olanlar ise, sertçe eleștirilmiștir. Bunun dıșında Milli mücadele döneminin karikatürlerinin bir diğer genel ve ortak özelliği ise düşmanı yenmek ve savaşçının maneviyatını yüksek tutmak maksadıyla ulusal güçleri öven, onları tanrısal varlıklar gibi gösteren çizimlerin oldukça fazla olmasıdır.

Cumhuriyet dönemi mizah ve karikatür anlayışı 1923 - 1928 döneminden sonra belirgin bir farklılaşmaya girdiği görülür. Temel özelliği eski yazı ile yazılmış olması ise, sosyal özelliği de yeni bir Cumhuriyet kurmanın, Kurtuluş Savaşı zaferinin sevincini dile getirmiş olmasıdır. Ayrıca dönem basınına bakıldığında Meşrutiyetten kalma çizer kadrosunun halen devam etmesinin yanında Osmanlı tipi tarikat örgütü ile Meşrutiyet tipi parti bu dönemde, Cumhuriyeti kuran partiye karşı iş birliği ve direniş içinde görünmüştür. ${ }^{21}$

Cumhuriyet'in ilk evresi kültür ve düşünce yönünde zengin ve hareketli olsa da Şeyh Sait Ayaklanması, Atatürk'e suikast ve çok partili döneme geçiş sürecinde ülke içerisinde yaşananlardan dolayı hükümet, basına Matbuat Genel Müdürlügü ya da basın savcılığı aracığıyla sansür getirmiş ve böylece basındaki çok sesliliğe son verilmiştir.

Çizerler, sakıncalı bilgilere pek girmeden ve üst düzeydeki kişileri doğrudan hedef seçmeden siyasal karikatür yapmakla yetinirler, belediye sorunlarını, vurgunculuğa, yolsuzluklara, pahalılığa, taşıt, su ve çöp konularına ağırlık vermişler ${ }^{22}$ ve özellikle cumhurbaşkanı Atatürk'ün, İnönü’nün, Başbakanların, Genelkurmay Başkanı ve komutanların karikatürlerinin "küçük düşürücü” ya da "alay konusu” olabilecek çizimlerden kaçınmışlardır.

Dönemin sansür uygulamaları, çizerleri kent yaşamına yönelterek, neredeyse her hafta konut sorunu üzerinde çalışmalar yapmışlardır. Cumhuriyet döneminden önce "kent" algısı yalnızca İstanbul'dan ibaretken, bu dönemde ikinci bir kent olarak Ankara ortaya çıkmaktadır.

20 Karagöz gibi resimsel olana bağlılı̆g varlık nedeni olarak gören bir karikatür anlayışı bile savaştan etkilenmiş, ayrıntılardan uzak, epeyce deformasyona kaymış bir karikatüre yönelmiştir. Milli Mücadele döneminde bazı yazarların arasında geçen “çizgi savaşları”, Türk karikatürüne kendiliğinden bir deformasyon kazandırmıştır.

21 Semih Balcıŏglu, Ferit Öngören, 50 Yılın Türk Mizah ve Karikatürü, Türkiye İş Bankası Yayınları, İstanbul 1973,s.70; Ferit Öngören, Cumhuriyet'in 75. Yılında Türk Mizahı ve Hicvi, Türkiye İş Bankası Yayınları, İstanbul 1998, s.76.

22 Hıfzı Topuz, Başlangıcından Bugüne Dünya Karikatürü, İnkılap Yayınevi, İstanbul 1997,s.139. 
Böylelikle Ankara, siyaseti; İstanbul ise kent yaşamını temsil etmiş ve Türk karikatürcüsü "yeni hayat"a adım atarak İstanbul dışındaki hayata, yaşama biçimlerine, yoksulluğu keşfetme sürecine girmiştir.

\section{ERKEN CUMHURIYET DÖNEMINDE TÜRKIYY'NIN MODERNLEŞME SÜRECINDE KARİKATÜRÜN İŞLEII}

Siyasi, iktisadi ve sosyo-kültürel alanlarının yeniden düzenlendiği Erken Cumhuriyet döneminde, yeni Türkiye'nin yaşadığı radikal bir değişime toplumu hazırlamak basının görevi olmuştur. Böylece gazeteciler ve idareciler bir yandan toplumu devrimlere teşvik etme çalışmaları sürdürürken, diğer yandan basın sade, anlaşılır bir dille kamuoyu oluşturmaktaydı. $\mathrm{Bu}$ nedenle ulus devlet inşa edilirken yönetici kesim, modernleşmenin birey üzerinden gerçekleşeceği düşüncesiyle, yeni topluma, yeni düzeni, hukuku ve siyaseti anlatabilmek için basını kapsamlı bir șekilde kullanmıștır. Ancak kullanılan basın tek yönlü ve tek sesli olarak uygulanmıştır.

Cumhuriyet döneminde de yayınlanmaya devam eden karikatür, bu dönemde gazete nüshalarında da görülmeye başlanmıștır. Meşrutiyet ve Milli Mücadele döneminden sonra yaşanan savaşların bitmesiyle başlayan kültürel değişimler çizgilere yansımış ve daha sonra da görülecek eski-yeni kıyaslaması mizahın başlıca konuları olmuştur. Murat Belge'ye göre, çizginin özerkleşmediği bu dönemde "söz"ün önceliği karşısında geri planda kalarak mizah asli görevini yerine getirememiştir. ${ }^{23}$

Erken cumhuriyet dönemin ilk dönemlerinde gerçekleșen yenileşme hareketlerinin eski yazı ile yazılmış olması bu dönemi farklı kılan etkenlerden biridir. Diğer ayrıcı özellikleri ise, on beş yıllık savaș sürecinin bitmesi karikatürlere yansımış ve geçmişte görülen keskin görüş ayrılıkları, çizgi savaşları bu dönemde yerini zafer coşkusuna "yeni” nin heyecanına birakmıştı.

1923 - 1925 dönemini kapsayan dönemde mizah, ilk süreçte bir taraf tutmak zorunda kalmadan çoğunlukla yaşanılan zafer sevincini işlemektedir. Uygur Kocabaşoğlu'nun serbestlik dönemi olarak adlandırdığı bu sürecin basınında kurulan devletin görüntüsü, taraflaşmalar ve iç siyasi gelişmelerle geçmişin hesaplaşmaları ortaya çıkmaktadır. Bu dönemde geçmişteki Milli Mücadele karşıtı gazeteler, Cumhuriyet'in kurulmasıyla bir yandan Ankara ile ilişkilerini düzeltmeye çalışırken diğer yandan Hilafet'in korunması ve sürdürülmesi konusunda iktidar ile karşı karşıya kalmıştır. ${ }^{24}$

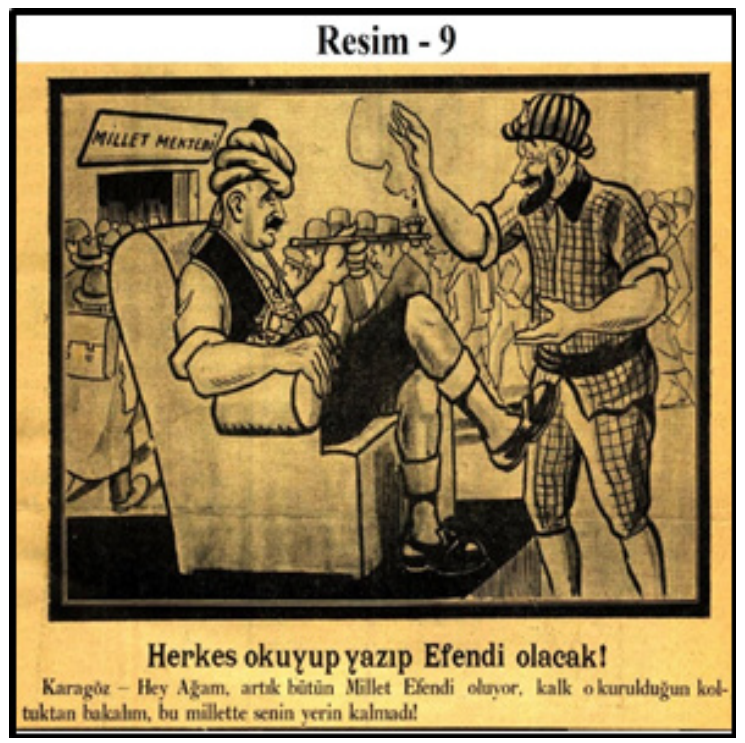

23 Turgut Çeviker, Karikatürkiye Tek Parti ve Demokrat Parti Dönemi (1923 - 1960) I, NTV Yayınları, İstanbul 2010, s.35.

24 Uygur Kocabaşoğlu,” 1919 - 1938 Dönemi Basınına Toplu Bir Bakış”, Ankara Üniversitesi Siyasal Bilgiler Fakültesi Basın Yayın Yüksekokulu Yıllı̆̆ı, Ankara 1981,s.110. 
Kültür ve düşünce hayatı yönünden renklilik gösteren bu dönemde, özellikle Akbaba ve Karagöz gibi yayınlar karikatürlerinde meclisi veya hükümeti rahatlıkla kullanabilmektedir. Bunun dışında genellikle milliyetçilik duyguları ön planda olan karikatürlerde eşitlikçi, imtiyazsız bir toplum yer almaktadır. Türklerden başka herkes düşman olarak gösterilmektedir. Asker hiç siyasi görüşün içerisinde yer almayan, bir vatansever olarak resmedilmişken, sevilmeyen istenmeyen kişiler frak giyimli silindir şapkalı "politikacı" olarak çizilmiştir.

Toplumun modernleştirilmesi için her alanda devrimlerin yapıldığı erken Cumhuriyet döneminin en önemli kitle iletişim aracı basın olmuştur. Böylece basın, devrimleri tanıtmada, toplumu oluşturan bireylerin zihinlerinde fikirsel dönüşümleri oluşturmada, yeni ulus

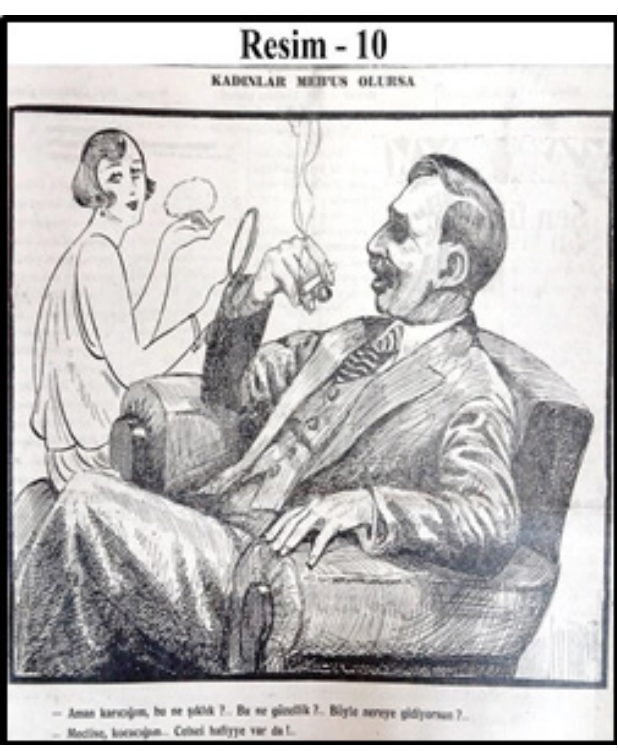
kimliğini şekillendirmede ve sistemin sürekli kendini yenileyerek daima en iyiye ulaștırmasını sağlayacak en etkili silah olduğu için okuma yazma bilgisinin yalnızca belli bir kesime ait olduğu bir ülkede, basın ile siyasi ve sosyal dönüşüm sağlanarak, fikir devrimi tamamlanmaya çalışılmıştır.

Cumhuriyet döneminde amaçlanan, Osmanlı döneminin aksine, modernleșmenin tepeden inme olarak değil, basın yoluyla halkın inkılaplara hazırlanması ve devrimlerin toplumsal yaşamın her alanında uygulanması olmuştur.

Cumhuriyet'in ilan edilmesinden sonra, yazılı basında olduğu gibi mizah basınında temel konu cumhuriyet ve toplumun henüz tanıdığı demokrasi kavramları olmuștur. Bu dönemde Cumhuriyet devrimlerinin ilk tohumları atılmış, yenilikler toplumsal hayatta kökleştirilmiye çalışılmıştır. Buna göre eski kültürün yerine yeni bir kültürün inșası sırasında geçmişin siyasi ve sosyal alışkanlıklarının bırakılması ve hatırlatacak herhangi bir yayının yapılmaması gerekmemektedir. Bu nedenle karikatürlerde, modernleşme ile Osmanlı Devleti'nin eskimiş köhne kurumları yıkılırken, yerine genç, dinamik ve toplumu devrimlerle medeniyete taşıyacak bir devlet kurulduğu görülmektedir (Resim-5). ${ }^{25}$ Böylece karikatürler sayesinde bir yandan Cumhuriyet' in tanımı yapılıp ve yararları anlatırken kamuoyu oluşturulmuş, diğer yandan muhalefet sesler çizgiler aracılığıyla deşifre edilmiştir. Bunun amacı ise, Cumhuriyet'in korunması, savunulması ve ülke içinde yaygınlaştırılması olup, basın modernleşmeyi, gelişmeyi sağlamak adına sorumluluğu üzerine almıştır.

Erken Cumhuriyet döneminin ilk sürecinde, mizah basını, eskinin biçemi ve kadrosuyla, yeni bir anlayış ortaya koymaya çalışmıştır. Ancak "yeni" nin meydana getirdiği sancılar ve denemeler, baskıya neden olmuş ve Türk basınında yaşanan renklilik ve canlılık, 1925 yılının ilk çeyreğinden itibaren gerçekleşen ayrılıkçı isyan hareketlerinden sonra yerini sıkıcı ve tekdüze bir görünüme bırakmıştı. Devamında isyanı bastırmak ve düzeni sağlamak için 4 Mart 1925'te çıkarılan Takrir-i Sükûn Kanunu ve sonrasında gerçekleşen İzmir Suikast'i ile

25 İmzası, Akbaba, 30 Teşrin-i Evvel 1340, no:199, s.1. 
basına gelen dolaylı sansür, işlenecek konuları da sınırlamıştır. ${ }^{26}$ Böylece Cumhuriyet'in ilk zamanlarında görülen kültür ve sosyal hayattaki canlılık çok uzun soluklu olmamış ve Şeyh Sait Ayaklanması, İzmir Suikasti gibi olaylar basındaki çeşitliliğin ve özgür ortamının önüne geçmiştir.

Piran Köyü'nde Şeyh Sait İsyanı'nın patlak vermesi üzerine tüm mizah basınında askeri harekâtın güncesi tutulmuş ve yaşanan gelişmeler halkın moralini yüksek tutmak ve cumhuriyet devrimlerinin gücünü göstermek amacıyla ayrıntılarıyla çizgilere taşınmıştır. (Resim-6) ${ }^{27}$. Ancak 4 Mart 1925'te Takrir-i Sûkun kanun teklifinin kabul edilmesinden sonra mizah günün koşulları uyum sağlayarak konu değişime uğramış ve dönem şartları ülkenin tüm alanlarını etkilediği gibi basını da etkilemiştir. Milli Mücadele döneminde ve Cumhuriyet'in ilk yıllarında görülen yönetim kadrosunun çizimlerine bu dönemde bulunmamaktadır. Nedeni de Cumhuriyet'in kurulmasıyla "eski" düzenin kaldırılması, "yeni” hayat için modernleşme sürecinde olunması ve ülke içerisinde ayrılıkçı hareketlerin yaşanması tek parti döneminin kendini eleştirilerden uzak tutması olarak yorumlanmalıdır.

Ülke içinde gerçekleşen siyasal gelişmeler, iktidarın basın üzerindeki kontrolünü arttırmasına sebep olmasının sonucunda ise yazılı ve görsel basın, siyasi olaylara ilişkin haber ve polemiklerden kendini uzak tutmak zorunda kalmıștır. Ayrıca basın kendini devam ettirebilmek maksadıyla, Tercüman-ı Ahval gazetesinden beri Osmanlı basınında kullanılan tefrikacılık ${ }^{28}$ akımı yeniden uygulamaya koymuş ve diş haberlere yönelim yaşanmıştı. Buna göre, hükümetin uyguladığı siyaset gereği ve çizerlerin kendi düşünceleri sayesinde mizah yeni bir biçim kazanmıştır. Böylece evrilerek gelişen mizah olgusu, bu dönem gerileme göstererek "Tanzimat Dönemi Basınına” na benzer bir şekil almıştır. Ayrıca bu dönemde, fotoğraf ve çizgi ile zenginleștirilmiş üstü kapalı bir cinsellik etkin kılınmaya çalışılmıştır. ${ }^{29}$

Bu dönemden önce meclis içi konuşmalar, yöneticiler kısmen mizahın malzemesi olsa bile, bu dönemden sonra mizahçılar çoğunlukla gündelik hayatı ve belediye konularını işlemişler, politik mizah resmi bir kimlik takınmıştır. Çok

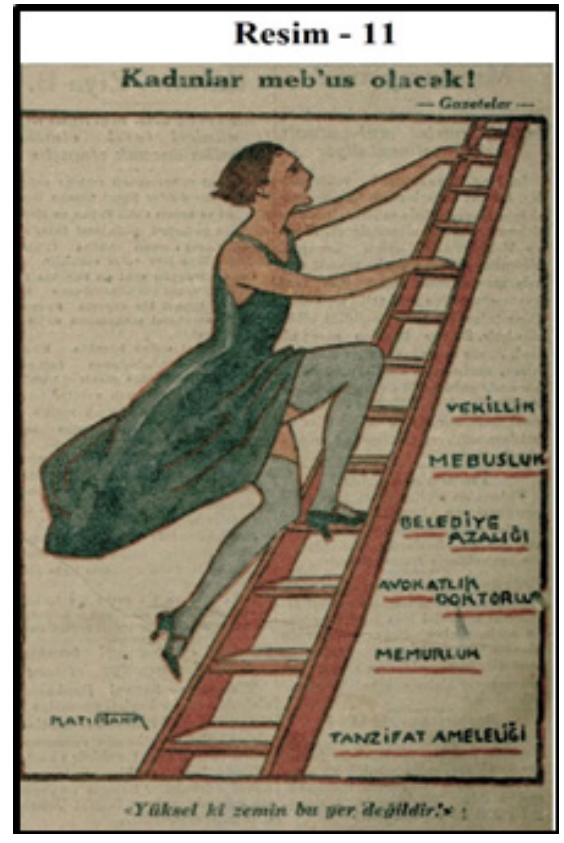
az çizer muhalif çizgisini devam ettirmek istemiş fakat kalemleri ya bir süreliğine veya süresiz olarak susturulmuştur. Böylece iç siyasi olayların yerine gündelik yaşam veya dünyadaki gelişmeler mizaha taşınmıș ve Cumhuriyet'in ve Milli

\footnotetext{
26 Takrir-i Sükun kanunu ile imtiyaz sahipliğini Zekeriya Sertel'in yaptı̆̆ Resimli Ay dergisi 18 Nisan 1925 yılında kapatılmış ve Sertel, İstiklal Mahkemesinde yargılanmıștı. Bkz. BCA, 30.18.1.1. / 13.24.2. Ayrıca Akbaba dergisi, 252. Sayısında yayınladığı "Meşhedîn'in Köpeği”" adlı yazı dizisinden dolayı İstanbul İstiklal Mahkemesine sevk edilmişti. Bkz. BCA, 30.18.1.1. / 14.34.4. dergide yer alan yazıyı görmek için bkz. Çekirge, Akbaba, 4 Mayıs 1341, no:252,s.2.

27 İmzasız, Karagöz, 11 Nisan 1341, no: 1780, s.4.

28 Tefrikacılık, gazete ve dergilerde çıkan, birbirini tamamlayan magazinsel yazı dizisidir. Tefrika edilen roman veya yazı, okuyucunun rahatlıkla bulabilmesi amacıyla, gazetenin hep aynı sayfasında ve aynı çerçeve içinde verilmektedir.

29 Kocabaşoğlu, a.g.m., s.111.
} 
Mücadele'nin yıldönümleri çizgilerle milliyetçi gündemi takip etmiştir. Bu sürede ele alınan diğer konular, uluslararası politikalar, meclis kürsüleri, İzmir ve diğer suikast teşebbüsleri, İstiklâl mahkemeleri ve yürüttügü yargılamalar, hükümetin ekonomik ve siyasi politikaları, belediye sorunları, Türkiye'nin dış politikası, bürokrasi içindeki yolsuzluklar olmuştur.

Cumhuriyet'in ilanından sonra gerçekleșen siyasal devrimlerinin kökleştirilmesi, yeni bir ulusun inşası ve toplumun eğitilebilmesi için kültürel politikalar planlanmış ve Milli Mücadele zaferi sonrasında Türkiye Devleti'nin yönetici kadrosu, Türk milletine milli kimliğini kazandırmak adına Türk kültürünün kaynaklarını bulma, işleme ve canlandırma esasına dayanarak, Türk kültürü üzerindeki yabancı tesirleri arındırmayı amaçlamıștır. ${ }^{30}$

Türk kültürünün egemenliğini ve bağımsızlığının sürdürülebilmesi, Türk çağdaşlaşmasının oluşturulması için bilim, teknik alanlarının geliştirilmesinin yanında laiklik ilkesinin gereksinimlerinin karșılanması gerekmiștir. Buna göre meclis, 3 Mart 1924 tarihinde 429 sayılı kanun ile "Şer'iyye ve Evkaf ve Erkan-ı Harbiye Vekâletlerinin İlgası", 430 sayılı kanun ile "Tevhid-i Tedrisat Kanunu" ve 431 sayll kanun

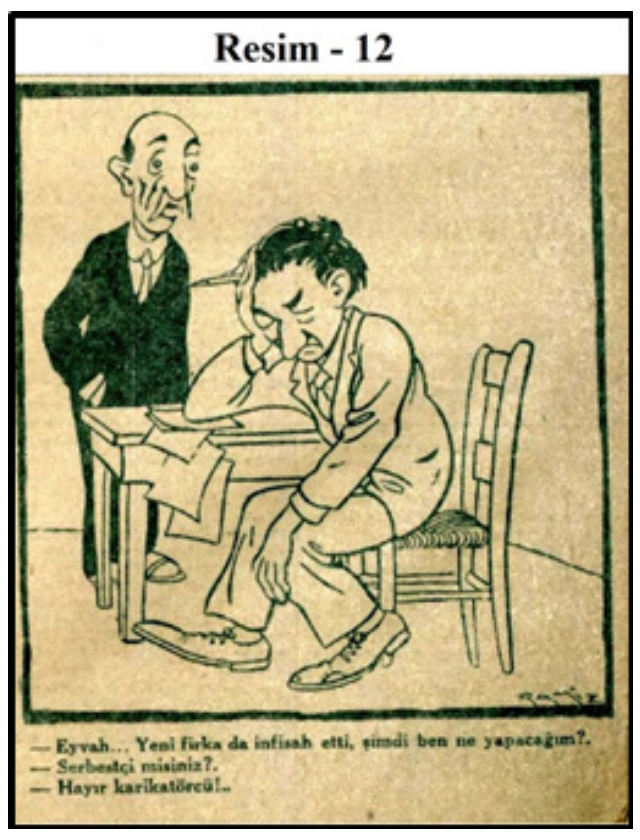
ile de "Hilafetin İlgasına ve Hanedan-1 Osmaninin Türkiye Cumhuriyeti Memalik-i Haricine Çıkarılmasını" kabul etmiştir. ${ }^{31}$ Ayrıca 1925 'te tekke ve zaviyeler kapatılmış, kllık klyafet değiştirilmiş ve 1926 yılında da Türk medeni kanun kabul edilmiștir. Böylece 1925'ten 1929'a kadar süren Takrir-i Sükûn döneminde, Türk toplumunun görüntüsü geleneksel kültür tipinden çıkarılarak, çağdaş ve modern bir yapıya dönüştürülerek ileride düşünülen köklü değișimlerin zemini hazırlanmıștır. (Resim7). ${ }^{32}$ Resimde de görüldüğü radikal modernleșme programı, geleneğin tümüyle tasfiye edilmesi şeklinde uygulanmaya geçirilmiştir. Dolayısıyla bu ortamda muhalif kimliği açısından mizah yayıncılığı en çorak dönemindedir ${ }^{33}$. Modernleșme paradigması aleyhine eleştirel bir yaklaşım söz konusu değildir.

Düşünülen ve uygulanması zorunluğu ile birlikte, kültürün en belirgin araçlarından biri olan yazının değişmesinin kültür değerlerini yok edeceği endişeleri karşısında, Cumhuriyet'in ilk yıllarından beri tartışılan harf devrimini Mustafa Kemal Paşa, halka 9 Temmuz 1928 tarihinde Sarayburnu Parkı'ndan yaptığı nutuk ile duyurmuş ve yönetici kadro, özellikle basın yoluyla Latin harflerinin fikri altyapısını oluştururken matbaa yoluyla da eylemsel hazırlığını başlatmışlardır. $\mathrm{Bu}$ anlayışla hareket edilmesi sonucu bu tarihten sonra ancak on beş yıl süreceği tahmin edilen devrimin hazırlıkları dört ayda tamamlanmıştır. ${ }^{34}$

30 Ayşegül Şentürk, "Harf İnkılabının Yapılışı ve Uygulanışında Basının Rolü”, Süleyman Demirel Üniversitesi Fen Edebiyat Fakültesi Sosyal Bilimler Dergisi, S.26, Ağustos 2012, s.29.

31 Düstur, Üçüncü Tertip, C.5, 3 Mart 1340, Başbakanlık Devlet Matbaası, Ankara 1955, s.227-236.

32 Ramiz, Akbaba, 13 Mart 1340, no:133, s.1.

33 Sertaç Timur Demir, Türkiye'de Mizah Dergileri Kültürel Hegemonya ve Muhalefet, İstanbul 2016, s. 17.

34 Milli Mücadele kazanıldıktan sonra Latin harfleri ile ilgili ilk önerge İzmir İktisat Kongresinde verilmiş ancak 
Türk modernleşmesinin en önemli aracı olan eğitimin her kesimde yaygınlaştırılabilmesi, okuryazar oranını artırarak bilgili ve tecrübeli kadroların oluşturulabilmesi, Türk kültürünü yabancı etkilerin hegemonyasından kurtararak Batı uygarlığına taşınmasını sağlayan 1 Kasım 1928 Harf İnkılabının ${ }^{35}$ kabul edilmesiyle Doğu düşüncesini simgeleyen Arap harflerinin yerine çağdaș medeniyetin alfabesi kullanılmaya bașlanmıștır. Böylece harf devrimiyle Türk toplumunda sadece kültürel ve sosyal alanda değişiklik yapılmamış siyasi bir hamle yapılarak Batı ile ilişkilerin geliştirilmesine ve medeni yaşamın aynı seviyeye taşınmasına çalışılmıştır.

Mustafa Kemal Paşa'nın Sarayburnu Parkı'ndaki konuşmasının ardından asıl mesele yeni Türk harflerinin uygulanması ve öğretilmesi olmuştur. Bunun üzerine bilimsel olan yeni harfleri topluma tanıtmak için kitaplar, broşürler basılmış, dershaneler açılmış, ülke içindeki levhalar değiştirilmiş ve gazete ve dergilerdeki başlık ve sütunlar Latin harfleri ile çıkmaya başlamıştır. Ülke içinde yürütülen okuma yazma seferberliğinde en önemli sorumluluğu basın üzerine almış ve gerek karikatürlerde gerek köșe yazılarında harf devrimini, Türkiye'nin modernleşmesi için yedi seneden beri aralıksız devam eden devrimlerin zorunlu sonucu olarak görmüştür. Böylelikle yazarlar, yeni Türkiye Devleti'ni ve Türkçeyi, Arapçanın hakimiyetinden kurtararak devlete milli bir kimlik verildiğini savunmuştur.(Resim-8). ${ }^{36}$ Akşam gazetesi başyazarı Necmeddin Sadak'ın "cehaletle mücadele" yazısında ${ }^{37}$, Doğu medeniyetinden Batı medeniyetine geçişte eğitimin önemli işlevlere sahip olması gerektiğini ve yeni devrimle kolaylaşan okuma yazma ile birlikte halkın düşüncesinin değișeceğini vurgulamıştır. ${ }^{38}$

Harf devrimi ile başlayan sosyal ve kültürel değişim süreç içerisinde, basında tamamen Cumhuriyet'in görüntüsü çizilmiş, eskiyi anımsatan hiçbir simge veya söz dizini kullanılmamıştır. Biçimin tamamen değişmesi içeriğin de değişmesine neden olmuştur. Böylece sesli harflerin çok kullanılmadığı Osmanlıca yazı dili, süslü ve ağdalı anlatıma neden olmaktadır. Oysa Latin harfli Türkçe yazısında daha kısa ve yalın bir anlatım kullanılmıştır. Ayrıca sağdan sola yazan çizerler daha yumuşak çizgilere sahipken, yazının soldan sağa yer değiştirmesi çizgilere de yansımış ve daha sert ve düz hareketler bașlamıştır. Ayrıca söz konusu dönemde hükümete karşı neredeyse hiçbir muhalif tutumla karşılașılmadığı gibi karikatürlerin genel konusu devrimleri halka anlatmak, Türkiye'nin dış ilişkileri ve belediye sorunları üzerine olmuştur. Ayrıca daha önceki dönemlerde sıkça karşılaşılan Mustafa Kemal' in hiçbir görüntüsü bu dönemde görülmemekle birlikte genellikle iç bürokrasi de İsmet Paşa ile Tevfik Rüştü Bey’in karikatürleri bulunmaktadır. Böylece en muhalif düşüncelerin bile Latin harflerinin kullanılarak ortaya konması bu dönemin gerek siyasal gerek toplumsal

İslam birliğini bozacağı gerekçesiyle Kazım Karabekir tarafından kabul edilmemiştir. Bkz. İmzasız, Hakimiyet-i Milliye, 5 Mart 1339, No:755, s.2. 1928 yılının başlarına kadar gerek basın üzerinden gazeteciler gerekse mecliste vekiller Harf devriminin olası faydalarını veya zararlarını tartışmışlardır. Resmi olarak atılan ilk adım ise, Afgan Kralı Amanullah Han'ın TBMM'yi ziyaret ettiği 20 Mayıs 1928 günü, Latin Rakamları tasarısının kabul edilmesi ve Dil Encümeni kurulmasıyla Afgan Kralı'na Türkiye'nin modernleştiği gösterilmiştir. Bilal Şimşir, Amerikan Belgelerinde Türk Yazı Devrimi, Türk Tarih Kurumu Yayınları, Ankara 1979, s.3. Dil encümenin kurduğu Latin harfleri komisyonu ile yeni Türk harfleri ile Fransız alfabesi incelenmiş ve 12 Ağustos'ta Mustafa Kemal Paşa'ya raporunu sunmuştur. Ayrıntılı bilgi için bkz. Neriman Tongul, "Türk Harf İnkılabı”, Ankara Üniversitesi Türk Inkılap Tarihi Enstitüsü Atatürk Yolu Dergisi, S.33-34, Mayıs-Kasım 2004, s.120.

35 TBMM Zabut Ceridesi, D.III, C.5, İ.II, 1.11.1928, s. 2-11.

36 İmzası, Yeni Köroğlu, 1 Birinci Kanun 1928, no: 63, s.1.

37 Necmeddin Sadak, “Cehaletle Mücadele”, Akşam, No:3590, 10 Teşrin-i Sani 1928, s.1.

38 Kemal Yakut, Pakize Yönter Sağun, “Gazeteci Necmeddin Sadık Sadak’ın Düşünce Dünyası”, Tercüman-ı Ahval'in 150. Yılında İstanbul'da Fikir Gazeteciliği Sempozyumu (21-22 Ekim 2010), (Ed. Belkıs Ulusoy Nalcıŏlu), İstanbul Üniversitesi Yayını, s.124. 
dönüm noktası olduğunu göstermektedir.

Kültürün en belirgin ve en etkin araçlarından biri olan yazının değişmesi, toplumun yeni bir çağdaşlaşma süreci için de kapı açmıştır. Yeni devletle ile birlikte eski alışkanlıkların ve eski kültürün yerine milli bir kültür oluşturmayı amaçlayan Harf devrimi, aynı zamanda medeniyetin yükselmesine yardımcı olmuştur. Dönem karikatürlerinde, yeni harflerin milletin zaferi olduğu ve eski kültürün son kırıntılarının da ortadan kaldırıldığı vurgulanarak okuma yazama kolaylığı sayesinde toplumun her kesiminin cehaletten kurtulacağı düşüncesi sıkça kullanılmıştır. Böylece basın, geçmiş diğer inkılaplarda olduğu gibi, harf devriminin kazanımlarını devlet yapısından sosyal hayata kadar tüm çevrelere aktararak, akılcı ve bilimsel, milli şuura sahip yeni nesillerinin yetişmesinin sağlamıştır. Sonuç olarak Türk basını, Türk modernleşmesinin oluşumunda büyük katkı sahibi olmuştur.

Hükümet, harf devrimini yaşayan Türk toplumuna yeni harfleri tanıtmak ve okuma yazma öğretmek için dil encümenliği tarafından hazırlanan yeni harfleri ve uygulamalarının içeren kitapçıklar, broșürler bastırmanın yanı sıra 24 Kasım’da iki, dört veya altı ay devam edecek ve gerekirse "gezici" niteliği taşıyabilecek Millet Mektepleri kanunu yürürlüğe sokmuștur. 1 Ocak 1929'da açllan Millet mektepleri ile 16 - 40 yaşındaki herkese zorunlu hale getirilerek okuma yazma seferberliği başlatılmış ve yılsonunda yaklaşık altı yüz bin vatandaşa okuryazarlık diploması verilmiştir. Böylece 1927 'de yapılan nüfus sayımına göre 13 milyon 648 bin nüfuslu Türkiye'de okuma yazma oranı \%19 iken, yürütülen çabalarla birlikte 1935 sayımında okuma yazma bilen kişi sayısı 2 milyona ulaşmıştır. ${ }^{39}$ Dil devriminin tamamlayıcı olan Millet mekteplerinin zorunluluğunu duyuran basın, karikatürler aracılı̆̆ıla mekteplerin içeriğine, toplumun modernleşmesindeki etkisine ve kazanımlarıyla ortaya çlkacak milli şuurun gerekliliği düşüncesine çizimlerinde yer vermiştir.(Resim-9). ${ }^{40}$

Millet Mekteplerinin yanında yeni yazıyı halka tanıtacak ve öğretecek en önemli kitle iletişim aracıda gazete ve dergiler, kasım ayında yürürlüğe giren kanunla birlikte yeni harfleri yalnızca karikatürde yer alan tabelalar gibi küçük alanlarda kullanmış olsa da, Kasım ayının son haftasından sonra basın yayına Latin harflerini kullanmak zorunluluğu getirilmiştir. Ancak söz konusu yeni dönemde, hem halkın yazılanları okuyabilme erişkinliğine ulaşmaması hem de matbaacıların yeni harflere alıșması, gazetelerin satışlarında önemli düşüșlere ve hatta gazetelerin çoğu kapanmasına neden olmuştu. Bu durum hükümeti, alınan gümrük vergilerini kaldırma, Matbuat Umum Müdürlüğü'ne gazetelere dağıtılması için para yardımında bulunma gibi önlemler almak zorunda bırakmış ve böylece uygulanan dolaylı baskının yanı sıra basın siyasal iktidara göre tefrikacılığın meydana getirdiği yozlaşmanın önüne geçebilmek maksadıyla Suphi Nuri İleri'nin nitelediği gibi "Drije Matbuat" dönemi başlamıștır. Böylece hem siyasi haber basınında hem de mizahi basında edebi konulara ve dıș haberlere yönelim dönemi başlamıştır. ${ }^{41}$

Kadın hakları üzerine tartışmalar II. Meşrutiyet döneminde ivme kazanmış ve kadınlar sosyal siyasal ve toplumsal haklarını dile getirmeye başlamışsa da ancak Cumhuriyet'in ilanına kadar etkili bir düzenleme yapılmamıştır. Cumhuriyet döneminin ilk girişimi Nezihe

39 İstatistik Göstergeler 1923 - 2011, TÜIK Yayınları, Ankara 2012, s.18.

40 İmzasız, Karagöz, 5 İkinci Kanun 1929, no:2171, s.1.

41 Kocabaşoğlu, a.g.m., s.112. 
Muhittin tarafından örgütlenen kadınlar tarafından kurulan ve parti nizamnamesine sahip Kadınlar Halk Fırkası olmuştur. Oluşturulan Beyannameye göre firkanın amacı ülke genelinde kadın hareketi başlatmak olsa da, dönemin şartlarından dolayı kesin bir sonuç yaratamamıştır. $1927^{\prime}$ de seçimlerinden beri yoğun çalışmalar yürüten Kadınlar Birliği'nin istedikleri haklarının uygulanmasının zamanını geldiğini düşünen CHF kadrosu, Türk kültüründe önemli bir yere sahip olan kadına siyasal haklar vermeyi, hem Türk devriminin devamı olarak hem de Tük modernleşmesinin tamamlayıcı unsuru olarak görmüştür. $\mathrm{Bu}$ nedenle Tevhid-i Tedrisat Yasası ve Medeni Hukuk Kanunu ile eșit seviyeye getirilen kadın-erkek, 1930 belediye seçimlerinde de eşit duruma getirilmiş ve iki parti üyesi tarafından aday

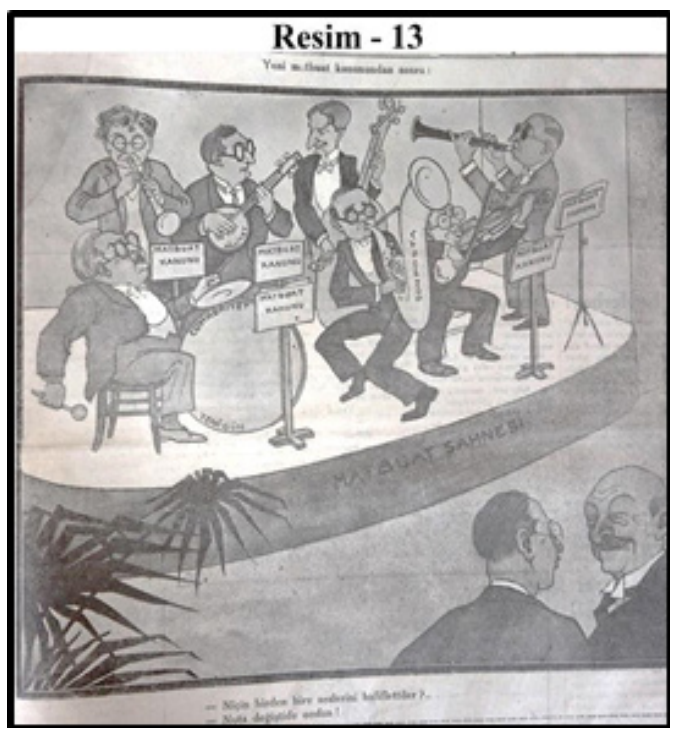
olarak gösterilen kadın, 18 yaşında seçme; 25 yaşında ise seçilme hakkını elde etmiştir. ${ }^{42}$ Böylece yeni Türkiye için Kurtuluş Savașı'nda mücadele veren Türk kadınının, demokrasinin sonucu olarak siyasal alanda da kendine yer bulmasıyla milli hakimiyetin tamamlanması için önemli bir adım atılmış ve Türkiye, demokrasi yolunda dönemin birçok Batılı devletlerinin önüne geçmiştir.

Dönem basını, II. Meşrutiyet döneminde olduğu gibi, Cumhuriyet'in ilan edilmesinden sonra da kadın hakları ve kadın meselesi konularını işlemeye devam etmiştir. Mizah basınında ise, mecliste mebus seçimlerinin değişikliğinin tartışıldığı günlerden kadının belediye seçimlerinde etkin olmasına kadar olan süreçte Akbaba, Zümrüd-ü Anka, Kelebek ve Güleryüz dergileri, "Kadınlar Halk Fırkası”nın açılmasıyla, kadınlar hakkındaki görüşlerini çizgilerine ve yazılarına taşıdığı görülmektedir. Akbaba ve Kelebek, kadının cinsel kimliğini ön plana alıp kadını oldukça açık Batılı giysiler içinde hem eşi için hem de diğer erkekler için ikna edici unsur olarak nitelemiștir.(Resim-10). ${ }^{43}$ Zümrüd-ü Anka, diğerlerine göre daha ağır şekilde hicvederek, çizimlerinde dedikoducu ve geveze kadına siyasi ve toplumsal hakların verilmesinin toplum düzenini bozacağını vurgulamıştır. Milli Mücadele döneminde söz konusu yayınların aksine yayın politikası yürüten Güleryüz, aynı politikasını kadın hakları konusunda da sürdürerek kadın-erkek eşitliğini savunmuştur. ${ }^{44}$ Kadının belediye seçimleri için kazandığı siyasi yetki sonrasında yalnızca Akbaba dergisi ve Cumhuriyet gazetesinde kadın hakları üzerine yayınlar bulunmaktadır. Akbaba bu dönemde, kalemini geçmişe kıyasla biraz daha

42 Kadınlara belediye seçimlerinde seçme ve seçilme hakkının tanınması ülke genelinde coşkuyla karşılanmıştır. Kadınların yönetime katılmasını sağlayan ikinci başarı ise 26 Ekim 1933'te değiștirilen "Köy Kanunu” ile verilen muhtarlık hakkı olmuştur. Böylece şehirdeki kadına tanınan hak, köydeki kadına da tanınmış ve kadının idari ve siyasi alandaki etkinliği arttırılmıştır. Belediye ve muhtarlık seçimlerinden sonra yetkinliğini ispatlayan Türk kadını, 5 Aralık 1934 tarihinde Teşkilat-1 Esasiye Kanunu'nun 10. ve 11. maddelerinde yer alan Mebus Seçimi Kanunu'nun değişmesiyle 22 yaşını bitiren kadın, erkek her Türk mebus seçme ve 30 yaşını bitiren kadın, erkek her Türk mebus seçilme hakkını sahip olmuştur. Düstur, Üçüncü Tertip, C.16, 5 Aralık 1934, Başbakanlık Devlet Matbaası, Ankara 1935, s.36. Ayrıca bkz. Suzan Ünal, “ Türk Kadının Seçme ve Seçilme Hakkının Kazanması ve Basın", Turkish Studies, C.9, S.7, (Yaz 2014), s.540-545; Sevilay Özer, "Kadınlara Seçme ve Seçilme Hakkı Verilmesinin Türk Kamuoyundaki Yankıları”, Atatürk Araştırma Merkezi Dergisi, C.29, S.85, Mart 2013, s.148.

43 İmzasiz, Akbaba, 24 Mart 1930, no: 758, s.1.

44 Hadiye Yılmaz, "1923 Yılı Mizah Basınında Kadınların Seçme ve Seçilme Hakkı ve Kadınlar Halk Fırkası", Ankara Üniversitesi Türk İnkllap Tarihi Enstitüsü Atatürk Yolu Dergisi, S.59, Güz 2016, s.271-287. 
yumuşatmış olsa da, çizimlerinde kadın yine süslü ve siyasetle ilgisiz olarak gösterilmiştir. Cumhuriyet gazetesi ise, kadını toplumsal, siyasal ve iktisadi hayatta görmekten onur duyan ve kadının siyasi katılımını Türkiye Cumhuriyeti'nin medeniyetini yükseltecek bir devrim olarak görmektedir. (Resim-11). ${ }^{45}$ Böylece basın kadının sosyal siyasal gelişimine sayfalarında yer vererek, toplumun algısındaki ev içinde yaşayan peçeli kadın figürünü ortadan kaldırılmasını amaçlayan zihinsel devrimin oluşumuna katkı sağlamıştır. Yayınlarda elinde bayrak taşıyan ve seçmen, avukat, doktor, öğretmen olan kadın, Türk modernleşmesinin simgesi, toplumsal hayatın yapı taşı olarak görülmüştür.

Yasalar çerçevesinde özgür olan basının hareket sahası, yoğun inkılap hareketlerinin yaşandığı Cumhuriyet'in ilk devresinde, Takrir-i Sükûn Kanunu ile daraltılmıştır. Böylece basın, toplumsal buhranların, belediyecilikte görülen aksaklıkların dışında devrimleri halka duyuran, milli toplum oluşturmaya çalışan ve yeni kurulan devlete karşı girişilen isyan hareketlerini değerlendiren yayınlar yapmak zorunda kalmıștır. Buna göre basının üzerindeki baskı, muhalif bir ruha sahip olmak zorunda olan mizahı körelttiği gibi, harf devriminden sonra matbaaların yaşadığı maddi kaygı birçok mizah dergisinin kapanmasına da sebep olmuş ve dergilerde, gazetelerden farklı olarak, yeni harflerin kabulünden sonra nicelik yönünden önemli bir artış görülmüștür. ${ }^{46}$ Ayrıca günün koşullarına direnen mizahi yayın organlarında görülen başlıca gündelik belediye sorunları ve yeniliklerin içeriği konuları, 1930'larda, ikinci çok partili döneme giriş çabalarının yaşandığı süreçte, önemli bir değişim yaşayarak karikatür mizahı kendine işleyecek yeni malzemeler yaratmış ve sevincini nüshalarına çekinmeden yansıtmıștır. Ağustos ayında başlayan bu mizahi hareketlilik, Serbest Cumhuriyet Fırkası'nın kendini feshetmesine 17 Kasım'a kadar, devam etmiş daha sonra ise yine tek seslilik dönemine girilmesiyle beraber çizerlerin mizah özgürlügü bir süreliğine, ülkedeki siyasi gelişmelerin doğal bir sonucu olarak, sansüre uğramıștır (Resim-12). ${ }^{47}$

Terakkiperver Cumhuriyet Fırkası'nın kurulmasından sonra, ülke içinde ortaya çıkan ayrışma ve kaosun basın aracığıyla gerçekleştiği düşüncesi üzerine Takrir-i Sükûn Kanunu ile çok gazete kapatılmış ${ }^{48}$ ve bu durum toplumun fikirsel bölünmelerine sebep olmuştu. Aynı sonuçların Menemen olayından ve Serbest Cumhuriyet Fırkası'ndan sonra da yaşanmasının önüne geçilebilmesi için, mecliste basın özgürlügünün kötüye kullanılmamasına dair önlemler alınması gerektiği görüşülmüştür. ${ }^{49} 25$ Temmuz 1931 tarihli Matbuat Kanunun 8 Ağustos'ta yürürlüğe girmesiyle, 1909 Matbuat Kanunu'nu yürürlükten kaldırmış ve buna göre Vatan, Milli Mücadele, Cumhuriyet ve devrimler aleyhinde, Padişahlık ve Hilafet yolunda halkı kışkırtan, TBMM üyeleri ve Bakanlar Kurulu’na karşı onur kırıcı yazı yazanlara, toplumun genel ahlakına ve kadının anne olma kimliğini zedeleyecek yayın yapanlara para ve hapis cezasının uygulanacağı kararı alınmıştır. Böylece mizah basını ülke içindeki siyasi gelişmelerden çok, yaklaşan ikinci dünya savaşının hazırlık evrelerini nüshalarına taşırken,

\footnotetext{
45 Ratip Tahir, Cumhuriyet, 28 Mart 1930, no: 2116, s.1.

46 Kocabaşoğlu, a.g.m., s.114.

47 Ramiz, Cumhuriyet, 23 Teşrin-i Sani 1930, no: 2352, s.1.

48 Takrir-i Sükûn Kanunu'nun 1. Maddesinde yer alan "irtica ve isyana ve ülkenin sosyal düzenin, huzur ve sükunu, emniyet ve asayişini ihlale yönelen örgüt, kışkırtma, özendirme, girişim ve yayını hükümet, Cumhurbaşkanının doğrudan onayı ile yasaklamaya yetkilidir” hükmü ile 1925 yılında Tevhid-i Efkar, İstiklal, Son Telgraf, Sebilürreşat, Tanin, Sada-yı Hak, Kahkaha, Vatan, Vakit gazeteleri kapatılmış ve gazete sahipleri istiklal mahkemelerinde yargılanmışlardır.

49 Meclisteki tartışmaların ayrıntısı için bkz. TBMM Zabıt Ceridesi, D.IV, C.III, İ.XXII, 5.7.1931, s.1-44.
} 
haber gazetelerinde yer alan karikatürler bölümleri de dönem şartlarından dolayı yavaş yavaş kaldırılmıştır. (Resim-13). ${ }^{50}$

Basının 1931 yılında Matbuat Kanunu ile bir düzenleme içine alınması, basının sosyalsiyasal hareketlerde toplumu şekillendirici ișlevinin olduğunu ve devlet yöneticilerinin bu etkin gücü kabul ettiğini göstermektedir. Bu durum ise yetkin bir basın sınıfının oluşmasına imkân vermekle birlikte daha sonraki süreçte sistemli birtakım politikalarla kurumsallaşan basın-yayın, dönemin modernleştirme yönündeki temel zihniyeti doğrultusunda toplumun kültürel birikimine katkı sağlamıştır.

\section{SONUÇ}

Türkiye'de bir dönemin düşünsel atmosferini ve zihinsel yapısını kavramak, mizah anlayışını görmek açısından önemli bir konumda bulunan mizahın/karikatürün, özellikle çizgi savaşlarının yaşandığı Milli Mücadele dönemini ve yeni bir toplum yapısının oluşturulmaya çalışıldığı, Erken Cumhuriyet dönemini değerlendirmede özel bir yeri vardır.

Türkiye gibi modernleşmeyi gecikmiş modernlik ekseninde yaşayan bir toplumda bu gecikmişliğin telafisiyönündegerekli zihniyet değișiminingerçekleşmesindemizah, dolayısıyla karikatür olağanüstü bir misyon üstlenmiştir. Hedeflenen toplumsal değişim yönünde en büyük engellerden birini teşkil eden yüzyıllar içinde oluşmuş ve adeta kemikleşmiş görünen geleneksel değer yargılarının aşındırılması ve terkedilmesi, modernleşme yönünde yeni bir hayat tarzı ve buna bağlı yeni değer yargılarının benimsenmesinde mizahın ve karikatürün kitleleri ikna edici gücünden yararlanılmıștır.

Modernleşme sürecinde değişimin öncülügünü yapan basın, mizahı da gardına alarak bu yöndeki değişime olan direnci kırmak için genel olarak devlet iktidarına yaslanmıştır. $\mathrm{Bu}$ durum, bu tür bir anlayışın bütünüyle devlet zihniyeti olarak benimsendiği özellikle erken Cumhuriyet dönemi için söz konusudur. 19. yüzyılda halen bir tercih konumunda yer alan modernleşme, bu döneme gelindiğinde ve öncesinde artık tam bir zorunluluktur. Bu zorunluluk, modernleşme projesi içinde yöntem olarak kaçınılmaz bir şekilde radikalizmi gündeme getirmiştir. Sürdürülen ödünsüz çağdaşlaşma/Batılılaşma süreci içinde yaşanılan sorunlar görmemezlikten gelinerek modernleşme programı tahakkuk ettirilmek istenmiştir. Özellikle II. Meşrutiyet döneminden itibaren artık konjonktürel değil, yer yer olgusal nitelik bir taşıyan monolitik medeniyet anlayışı ve zihniyet ortamında mizahtaki eleştiri de bundan payını almıştır. Esasen bu durum mizah geleneği açısından bütünüyle söz konusudur. Genel olarak dönüştürülmek istenilen toplum mizahın temel nesnesidir. Bu süreçte basın, bütünüyle devlet desteğiyle, Cumhuriyet'in kuruluş amaçlarını ve ideallerini açıklamaya ve modernleşme hedeflerinin gerçekleştirilmesine odaklanmıştır. Tek Parti dönemi felsefesinin bir yansıması olarak mizah dergileri 1923 Devrimi'nin bir tanıtım kataloğu gibidir ${ }^{51}$. Bu durum karikatürdeki çizgilere de aynen yansımıştır. Buna rağmen birçok mizah tarihçisi, paradoksal olarak, Cumhuriyet mizahının geleneksel -yani bilim dışı- kalıplarını yıkarak renkli ve zengin bir mizah algısı oluşturduğu görüşündedir. Politik mizah Cumhuriyet'in ilanıyla resmi kimliğe bürünmüştür. Cumhuriyet kültürü; sosyal alanda Ortaçağ’ın dar ve eski

50 İsimsiz, Akbaba, 30 Temmuz 1931, no:864, s.1.

51 Demir, a.g.e., s. 17. 
çemberinden kurtulmayı bilimsel olmak anlamında Batı kültürüne açılmayı ifade etmiştir. Bu köklü dönüşüm, Cumhuriyet mizahının da temel yapısını belirlemiştir. Bu dönemde yaşanılan değişim, Refik Halid'in, Deli adlı tiyatro oyununa ilham verecek boyutlara ulaşmıştır. Basın, mizah ve karikatür bu değişimin temel dinamikleri arsında yer almıştır.

\section{KAYNAKÇA}

\section{Arşiv belgeleri ve Resmi Kaynaklar}

Başbakanlık Cumhuriyet Arşivi, 30.18.1.1. / 13.24.2.

Başbakanlık Cumhuriyet Arşivi, 30.18.1.1. / 14.34.4.

TBMM Zabit Ceridesi, D.III, C.5, İ.II, 1.11.1928.

TBMM Zabıt Ceridesi, D.IV, C.III, İ.XXII, 5.7.1931.

Düstur, Üçüncü Tertip, C.5, 3 Mart 1340, Başbakanlık Devlet Matbaası, Ankara 1955.

Düstur, Üçüncü Tertip, C.16, 5 Aralık 1934, Başbakanlık Devlet Matbaası, Ankara 1935.

Süreli Yayınlar

Cem, Cemil, Kalem, 8 Kanun-i Sani 1324, no:21, s.1.

Cimcoz, Salah, Kalem, 21 Ağustos 1324, no:1, s.3.

Çekirge, Akbaba, 4 Mayıs 1341, no:252, s.2.

İmzasız, Akbaba, 30 Teşrin-i Evvel 1340, no:199, s.1.

----------------, Karagöz, 11 Nisan 1341, no: 1780, s.4.

------------, Yeni Köroğlu, 1 Birinci Kanun 1928, no: 63, s.1.

-------------, Karagöz, 5 İkinci Kanun 1929, no:2171, s.1.

-------------, Akbaba, 24 Mart 1930, no: 758, s.1.

-, Hakimiyet-i Milliye, 5 Mart 1339, No:755, s.2.

Kasab, Teodor, Diyojen, 12 Teşrin-i Sani 1289, no:1, s.1.

Fehim, Münif, Kelebek, 24 Mayıs 1339, no:7, s.1.

Sadak, Necmeddin, “Cehaletle Mücadele”, Akşam, No:3590, 10 Teşrin-i Sani 1928, s.1. 
Simavi, Sedat, Güleryüz, 17 Ağustos 1338, no:70, s.1.

Ramiz, Akbaba, 13 Mart 1340, no:133, s.1.

-------------, Akbaba, 30 Temmuz 1931, no:864, s.1.

-, Cumhuriyet, 23 Teşrin-i Sani 1930, no: 2352, s.1.

Tahir, Ratip, Cumhuriyet, 28 Mart 1930, no: 2116, s.1.

Araştırma ve İnceleme Eserler

Akbaba, Bülent - Birbudak, Togay Seçkin, "Milli Mücadele ve Cumhuriyet Dönemi Mizah Basınında Mustafa Kemal Atatürk İmajı", Gazi Üniversitesi Gazi Eğitim Dergisi, C.2, Özel Sayı, Ankara 2009, s.1251-1274.

Balcığlu, Semih - Öngören, Ferit, 50 Yılın Türk Mizah ve Karikatürü, Türkiye İş Bankası Yayınları, İstanbul 1973.

Berkes, Niyazi, Türkiye'de Çağdaşlaşma, Yay. Haz. Ahmet Kuyaş, Yapı Kredi Yayınları, İstanbul 2011.

Çapanoğlu, Münir Süleyman, Basın Tarihimizde Mizah Dergileri, Garanti Matbaası, İstanbul 1970.

Çeviker, Turgut, Gelişim Sürecinde Türk Karikatürü-I Tanzimat ve İstibdat Dönemi (18671878/1878-1908), Adam Yayınları, İstanbul 1986.

Adam Yayınları, İstanbul 1991.

-------------, Gelişim Sürecinde Türk Karikatürü-III Kurtuluş Savaşı Dönemi (1918-1923),

------------, Karikatürkiye Tek Parti ve Demokrat Parti Dönemi (1923 - 1960) I, NTV Yayınları, İstanbul 2010.

Demir, Sertaç Timur, Türkiye'de Mizah Dergileri Kültürel Hegemonya ve Muhalefet, İstanbul 2016. 1959.

Ersoy, Osman, Türkiye’ye Matbaanın Girişi ve İlk Basılan Eserler, Güven Basımevi, Ankara

Gerçek, Selim Nüzhet, Türk Matbaacılığı I Müteferrika Matbaası, MaarifVekâleti Yayınları, İstanbul 1939

Halıcı, Şaduman - Burgaç, Murat, Altı Ok (1919-1938), Kaynak Yayınları, İstanbul 2016.

İnuğur, Mustafa Nuri, Basın ve Yayın Tarihi, Çağlayan Kitabevi, İstanbul 1982. 
İstatistik Göstergeler 1923 - 2011, TÜİK Yayınları, Ankara 2012.

Kocabaşoğlu, Uygur, " 1919 - 1938 Dönemi Basınına Toplu Bir Bakış”, Ankara Üniversitesi Siyasal Bilgiler Fakültesi Basın Yayın Yüksekokulu Yıllığı, Ankara 1981, ss.95 - 127.

Koloğlu, Orhan, Osmanlı'dan 21. Yüzyıla Basın Tarihi, İsta nbul 2006.

Lewis, Bernard, Modern Türkiye'nin Doğuşu, TTK Basımevi, Ankara 2004.

Mardin, Şerif, Türk Modernleşmesi Makaleler 4, İletişim Yayınları, İstanbul 1992.

Öngören, Ferit, Cumhuriyet'in 75. Yılında Türk Mizahı ve Hicvi, Türkiye İș Bankası Yayınları, İstanbul 1998.

Özer, Atilla, Karikatür Yazıları, Anadolu Üniversitesi Yayınları, Eskişehir 2007.

Özer, Sevilay, "Kadınlara Seçme ve Seçilme Hakkı Verilmesinin Türk Kamuoyundaki Yankıları”, Atatürk Araștırma Merkezi Dergisi, C.29, S.85, Mart 2013, s.131 - 167.

Shaw Stanford J. - Shaw, Ezel Kural Shaw, Osmanlı Imparatorluğu ve Modern Türkiye, E Yayınları, İstanbul 1994.

Şentürk, Ayşegül, "Harf İnkılabının Yapılışı ve Uygulanışında Basının Rolü”, Süleyman Demirel Üniversitesi Fen Edebiyat Fakültesi Sosyal Bilimler Dergisi, S.26, Ağustos 2012, s.27 44.

Şimşir, Bilal, Amerikan Belgelerinde Türk Yazı Devrimi, Türk Tarih Kurumu Yayınları, Ankara 1979.

Tongul, Neriman, "Türk Harf İnkılabı", Ankara Üniversitesi Türk Inkılap Tarihi Enstitüsü Atatürk Yolu Dergisi, S.33-34, Mayıs-Kasım 2004, ss.103 - 130.

Topuz, Hıfzı, Başlangıcından Bugüne Dünya Karikatürü, İnkılap Yayınevi, İstanbul 1997.

Ünal, Suzan, “ Türk Kadının Seçme ve Seçilme Hakkının Kazanması ve Basın”, Turkish Studies, C.9, S.7, (Yaz 2014), s.525 -559.

Yakut, Kemal - Yönter Sağun, Pakize, "Gazeteci Necmeddin Sadık Sadak'ın Düșünce Dünyası", Tercüman-ı Ahval'in 150. Yılında İstanbul'da Fikir Gazeteciliği Sempozyumu (21-22 Ekim 2010), (Ed. Belkıs Ulusoy Nalcıoğlu), İstanbul Üniversitesi Yayını, ss. 115 - 126.

Yılmaz, Hadiye, "1923 Yılı Mizah Basınında Kadınların Seçme ve Seçilme Hakkı ve Kadınlar Halk Fırkası”, Ankara Üniversitesi Türk İnklap Tarihi Enstitüsü Atatürk Yolu Dergisi, S.59, Güz 2016, s.263 - 296. 